\title{
Reproductive strategy of forkbeard, Phycis phycis, from the Portuguese coast
}

\author{
Ana Rita Vieira ${ }^{1,2^{*}}$, Vera Sequeira ${ }^{1}$, Ana Neves ${ }^{1,2}$, Rafaela Barros Paiva ${ }^{1,2}$ and Leonel Serrano Gordo ${ }^{1,2}$
}

\begin{abstract}
Knowing fish reproductive strategy is essential for understanding population dynamics. This study intends to define the spawning season, length at first maturity, fecundity type, and estimate fecundity of forkbeard, Phycis phycis, from the Portuguese coast. Monthly samples collected from commercial landings between May 2011 and December 2012 were used. Results show that forkbeard is a group-synchronous and batch spawner species. Mature females were found between September and January, mature males were found between August and January, and a significant concomitant increase in gonadosomatic index suggests a spawning season from September to January. Length at first maturity was estimated as 35.9 and $28.5 \mathrm{~cm}$ TL for females and males, respectively. Reproductive abnormalitiesmosaic intersex, follicular cysts in ovaries, and early mature males - were detected. For fecundity-type definition, a hiatus between primary and secondary growth oocytes was detected. A significant increase in the mean diameter of secondary growth oocytes and a decreasing trend in their number during the spawning season were observed. The intensity of a-atresia was low throughout the spawning season. These four criteria suggest that forkbeard has determinate fecundity. Mean relative annual fecundity estimated was $1833 \pm 857$ oocytes $\mathrm{g}^{-1}$ gutted weight. Nonreproductive females that skipped a spawning season attained $36.1 \%$.
\end{abstract}

Keywords: Reproductive strategy, First maturity, Determinate fecundity, Skipped spawning, Forkbeard, Phycis phycis

\section{Background}

The knowledge of life history traits of a fish species is essential for a comprehensive understanding of the population dynamics [24] and an essential key to identify and further assess fish stocks [56]. Among life history traits, studies on reproduction, including timing and duration of spawning, the assessment of maturity size, and fecundity, permit the comprehension of the reproductive strategy of the species [47]. These, together with egg size, viability, and hatching success, permit to evaluate the reproductive potential. Among the wide range parameters for studying reproduction, fecundity is probably one that has the widest application since it is included in life history tables, in estimates of spawning stock biomass and in recruitment analysis [34].

\footnotetext{
*Correspondence: arivieira@fc.ul.pt

${ }^{1}$ MARE - Marine and Environmental Sciences Centre, Faculdade de Ciências, Universidade de Lisboa, Campo Grande, 1749-016 Lisbon, Portugal

Full list of author information is available at the end of the article
}

Two types of fecundity have been identified, these being determinate and indeterminate [27]. In fish species with determinate fecundity, this is fixed before the onset of spawning, and the number of yolked oocytes prior to the beginning of spawning is considered equivalent to the potential annual fecundity $[47,27]$. In these species, total annual fecundity is estimated after discounting oocyte atresia from potential fecundity. For species with indeterminate fecundity, a continuous recruitment of oocytes into vitellogenesis during the spawning season occurs, and therefore, fecundity is not fixed before the onset of spawning $[47,27]$. Thus, annual fecundity should be estimated from batch fecundity, spawning fraction, and the duration of the individual spawning season [27].

The forkbeard Phycis phycis (Linnaeus, 1766) is a gadiform benthopelagic fish that occurs in the Northeast Atlantic from the Bay of Biscay to Morocco, Macaronesia islands, and in the Mediterranean Sea [10]. It lives on hard and sandy-muddy bottoms near rocks at depths up to $650 \mathrm{~m}$ [10], where it takes refuge in holes during the day and becomes an active predator during the night $[10,46$, 
54]. In the southern NE Atlantic, forkbeard is an important commercial species in both Portugal and Spain, with landings in Portugal showing an increasing trend since the 1990s and reaching about 800 tons per year in the last 5 years [29]. In Spain, landings also showed an increasing trend from 250 tons per year (in the early 2000s) to 4000 tons per year in the last 5 years [13]. In Portuguese waters, the fishery ranges from coastal waters to offshore seamounts in mainland, and also in the Azores and Madeira archipelagos. The forkbeard is not a target species, being mainly caught by a longline fishery, with trawl, trammel net, and trap fisheries contributing to a small percentage of the total landings. This species still lies in the category of developing fishery despite being one of the most important gadiform species commercially exploited by the Portuguese fleet, together with European hake Merluccius merluccius (Linnaeus, 1758), pouting Trisopterus luscus (Linnaeus, 1758), and blue whiting Micromesistius poutassou (Risso, 1827) [29]. Despite the commercial importance of the forkbeard, no information on the reproductive strategy of this species exists. Some parameters, such as the spawning season and length at first maturity, have already been described for specimens from the Azores [69] and the Adriatic Sea [18]. Therefore, this study intends to define the reproductive strategy of forkbeard from the Portuguese continental coast. The main objectives are as follows: (1) to characterize the gonads structure; (2) to define the spawning season; (3) to estimate the length at first maturity; (4) to characterize the fecundity type; and (5) to estimate fecundity of the forkbeard. This information will be important for understanding the reproductive potential of this species.

\section{Methods}

\section{Sampling}

A total of 690 forkbeard specimens were collected on a monthly basis $(38 \pm 17$ specimens per month, mean $\pm \mathrm{SD}$ ) from commercial landings of fishing vessels operating off mainland Portugal (Peniche, central west coast), using longline, trawl, trammel net, and traps, from May 2011 to December 2012. For each fish, total length (TL, to the nearest $0.1 \mathrm{~cm}$ ), gutted weight (GW, to the nearest $0.01 \mathrm{~g}$ ), gonad and liver weights (gonW and livW, respectively, to the nearest $0.01 \mathrm{~g}$ ), and sex were recorded. Macroscopic sex was assigned, and maturity phases were confirmed by histological examination. Gonads were removed and preserved in a $10 \%$ buffered formaldehyde solution.

\section{Histology}

Gonad slices were taken, dehydrated with ethanol, and embedded in methacrylate. Two sections $(3-5 \mu \mathrm{m})$ were cut from each slice, stained with toluidine blue, and examined and digitized using a Leica DM 2000 light microscope with a Leica DFC 290 digital camera. Homogeneity of oocyte distribution within and between ovaries was tested to verify whether the development in the middle region of any ovary was representative of the entire gonad. For this, slices from anterior, middle, and posterior regions of the right ovary, and from middle region of left ovary were taken. Comparisons were made using 8 spawning-capable (SC) and 8 actively spawning (AS) females without visible post-ovulatory follicles (POF). Since no significant differences in oocyte size distribution between ovary regions (MANOVA: $P=0.06$ ) or between ovaries (MANOVA: $P=0.06$ ) were found, the analysis continued only using middle ovary sections.

To describe and characterize oogenesis, oocytes were classified into stages of development based on the histological criteria suggested by Wallace and Selman [76] and were divided into stages, proposed by Lowerre-Barbieri et al. [42]: primary growth (PG), cortical alveolar (CA), primary vitellogenic (Vtg1), secondary vitellogenic (Vtg2), tertiary vitellogenic (Vtg3), germinal vesicle migration (GVM), germinal vesicle breakdown and yolk coalescence (GVBD \& YC), and hydrated (H). POF and atretic oocytes (A) were also recorded. For spermatogenesis characterization, description of spermatogenic stages was based on the classification of Grier and UribeAranzábal [21] and included spermatogonia (Sg), primary spermatocytes (Sc1), secondary spermatocytes (Sc2), spermatids (St), and spermatozoa (Sz). To characterize each stage of oogenesis and spermatogenesis, digitized images of histological sections of 23 females $(40 \times$ or $100 \times$ magnification) and 5 males $(200 \times$ magnification) were analysed. Around 1300 oocytes with visible nucleus and 1200 male germ cells were measured, using the software package Image-Pro Plus, for maximum and minimum diameter and averaged afterwards, in order to decrease the variance caused by the histological processing.

Histological classification of gonads was based on the development stage of the most advanced cellular type, and maturity phases were assigned according to the standardized terminology proposed by Brown-Peterson et al. [7]: immature (I), developing (D), spawning capable (SC) and its actively spawning subphase (AS) (only for females), regressing (RE), and regenerating $(\mathrm{R})$.

\section{Sexual cycle and length at first maturity}

After the characterization of each maturity phase, their monthly frequency was investigated for both sexes in order to determine the spawning season of the forkbeard. This analysis was further corroborated with the monthly evolution of the gonadosomatic index [GSI $=$ (gonW/ $\mathrm{GW}) \times 100]$. Two bioenergetic indices were also 
analysed, the hepatosomatic index [HSI $=(\operatorname{livW} /$ $\mathrm{GW}) \times 100]$ and the Fulton's condition factor $[K=(\mathrm{GW} /$ $\left.\mathrm{TL}^{3}\right) \times 100$ ], to assess fish condition.

Based on the fraction of mature specimens of both sexes per TL class, the maturity ogive was estimated for females and males adjusting a logistic model proposed by Figueiredo et al. [14]. Length at first maturity $\left(L_{50}\right)$ for each sex was estimated as $L_{50}=-a / b$ ( $a$ and $b$ are model parameters).

Since not all individuals within the population follow the normal reproductive development schedule [65], gonads that were considered abnormal in relation to other specimens were registered.

\section{Fecundity}

To investigate the fecundity type of forkbeard, four lines of evidence suggested by Hunter et al. [27], Greer-Walker et al. [20], and Murua and Saborido-Rey [49] were examined as follows: (1) the presence or absence of an hiatus between pre-vitellogenic and vitellogenic oocytes; (2) the mean diameter of the advanced vitellogenic oocytes in the standing stock over the spawning season; (3) the number of vitellogenic oocytes in the ovary during the spawning season; and (4) the intensity of atresia over the spawning season. The first line of evidence was evaluated using digitized images of histological sections from $7 \mathrm{SC}$ and 5 AS females (41.9-56.9 cm TL; September: 5 SC; October: 1 SC, 2 AS; November: 1 SC, 2 AS; December: $1 \mathrm{AS}$ ) without POF during the spawning season. All oocytes were measured as described previously for gametogenesis stages characterization.

The second and third lines of evidence were evaluated by the gravimetric method [26] using $18 \mathrm{SC}$ and $17 \mathrm{AS}$ females (45.7-66.6 cm TL; September: 1 SC; October: 1 SC, 3 AS; November: 9 SC, 5 AS; December: 6 SC, 9 AS; January: $1 \mathrm{SC}$ ) with visible POF (confirmed in histological sections). From each ovary, one sample of approximately $0.03 \mathrm{~g}$ was analysed. Oocytes were separated from each other and from connective tissue by flushing them with tap water into a $125-\mu \mathrm{m}$ mesh sieve (threshold size fixed for CA oocytes by measuring each type of oocyte in histological sections, as previously described). Then, sample was placed on a watch glass dish under a stereomicroscope for image acquisition. Some additional work with needles and forceps was required to separate some oocytes that remained together. All oocytes were automatically measured and counted using ImageJ software (http://imagej.nih.gov/ij/) added with the ObjectJ plugin (https://sils.fnwi.uva.nl/bcb/objectj/). Oocytes that were not detected automatically had to be measured and counted manually. Analysis of variance (ANOVA) and post hoc Fisher's LSD test were used to detected significant statistical differences in mean oocyte diameter throughout the spawning season. As mean number of oocytes data were not normal even after transformation, a permutational MANOVA (PERMANOVA) [2], based on the Bray-Curtis distance dissimilarities [6], was used to detect significant statistical differences throughout the spawning season.

For the fourth line of evidence, relative intensity of atresia was calculated as the percentage of $\alpha$-atretic vitellogenic oocytes [25] in relation to total number of normal and atretic vitellogenic oocytes in an ovary [37, 78], using histological sections of $18 \mathrm{SC}$ and $16 \mathrm{AS}$ females (43.0-66.6 cm TL; September: 7 SC; October: 2 SC, 4 AS; November: 5 SC, 4 AS; December: 3 SC, 8 AS; January: 1 SC). ANOVA was used to compare relative intensity of $\alpha$-atresia throughout the spawning season.

To estimate potential annual fecundity, the gravimetric method was used and the number of secondary growth oocytes (CA-H) was counted. Histological sections were examined to select ovaries without POF, given that their presence indicates that spawning has already begun and the potential fecundity would be underestimated [47]. Seven SC and 16 AS females (43.0-61.5 cm TL) without POF were selected throughout the spawning season. From each ovary, three subsamples of $0.06 \pm 0.02 \mathrm{~g}$ were analysed. Total annual fecundity was calculated after discounting atretic losses from potential annual fecundity $[47,27]$.

\section{Skipped spawning}

To detect the presence of females that skipped a spawning season, only the time period from October to December (reproductive peak) was considered. Large females (with TL $>L_{50}$ ) with non-reproductive ovaries (i.e. without advanced vitellogenic or hydrated oocytes) (D, RE and $\mathrm{R}$ females) and/or when an entire cohort of developing oocytes was atretic (i.e. mass atresia) were classified as skipped spawners. For these females, GSI, HSI, and $K$ were compared with the same indices of reproductive females for the same period of time, using the Student's $t$ test. The frequency of skipped spawning by year was calculated as the number of non-reproductive females divided by the total number of mature females sampled [63].

\section{Statistical analysis}

All statistical analysis used in this study were performed in Statistica software version 11, with the exception of $L_{50}$ and PERMANOVA, which were performed using $\mathrm{R}$ version 2.15.1, and PRIMER 6 and its add-on package PERMANOVA+, respectively. The significance level was set at 0.05 for all statistical tests used. 


\section{Results}

\section{Gonads characterization}

A total of 369 females (18.8-66.6 cm TL) and 320 males $(15.5-67.1 \mathrm{~cm}$ TL) were used in this study for characterization of gonads structure and maturity phases.

Macroscopically, forkbeard ovaries consist in two elliptic shape lobes, fused posteriorly, whose colour varies from whitish to pink, yellow, orange and red, as maturity progresses. Testes are dorso-ventrally compressed, with ruffles, fused posteriorly, and their colour varies between pink, white and red throughout maturation.

From the histological examination of gonads, it was possible to identify all oocyte stages and male germ cells. Oocyte development is group-synchronous showing two cohorts of oocytes, one of primary growth and other of secondary growth oocytes (Fig. 1a). The latter are the oocytes to be spawned during the current spawning season and the former are the "reserve fund" oocytes, to be spawned in future spawning seasons. Hydrated and vitellogenic oocytes and POF could be observed simultaneously in AS females (Fig. 1b), suggesting a batch spawner pattern. Description of each oocyte development stage and respective diameter are presented in Table 1.

Forkbeard testicular tissue is organized into lobules, consisting on many seminiferous tubules containing cysts. Each cyst is formed by spermatogenic cells in the same stage of development and bounded by a thin layer of connective tissue. Spermatogenesis is cystic and synchronous (Fig. 1c). Description of each spermatogenic cell stage and respective diameter are presented in Table 2 .

\section{Sexual cycle}

A total of 307 females (31.9-66.6 cm TL) and 303 (26.1$67.1 \mathrm{~cm} \mathrm{TL})$ males were used. Immature specimens were excluded from this analysis.

For females, D phase was found throughout the year except in January, February, May, and December. SC females occurred between September and January, and AS phase was found between October and December. Females in RE phase were present in January, March, and April, and R females occurred between January and June (Fig. 2a). Monthly mean GSI and HSI values of females were statistically significantly different throughout the year (Kruskal-Wallis test: $P<0.001$ ). GSI showed higher values from September to January with a peak in November and December (6.0\%), whereas HSI presented an increasing trend from August to February, with a peak in the latter (6.9\%) (Fig. 3a). $K$ values had significant fluctuations during the year, but without a clear trend (ANOVA: $P<0.0001$ ) (Fig. 3a). Female GSI was significantly related with HSI $(r=0.30, P<0.0001)$, although the determination coefficient was low, but not with $K$ $(P=0.180)$.

For males, D phase was present between January and October, SC between August and January, RE from October to March (except February), and R between October and July (Fig. 2b). Monthly means values of GSI and HSI were significantly different throughout the year (KruskalWallis test: $P<0.05$ ) whereas $K$ showed no significant variations (Kruskal-Wallis test: $P=0.06$ ). GSI showed higher values between August and December, with peaks in September $(0.77 \%)$ and November (0.71 \%) (Fig. 3b). HSI presented three peaks throughout the year, namely in January (4.9\%), March (4.7\%), and September (5.0\%) (Fig. 3b). Male GSI was significantly related with HSI $(r=0.21, P=0.0007)$ and with $K(r=0.24, P<0.0001)$, although the determination coefficient was too low to be considered as a strong correlation.

Based on these results, forkbeard spawning season was considered to occur from September to early January (the time period between the appearance of the first and the last SC female), with a peak between October and December (when AS females were detected). However, results indicate that males were reproductively active (SC) for a longer period than females (from August to January).

\section{Length at first maturity}

The smallest mature female and male sampled measured 31.9 and $26.1 \mathrm{~cm}$ TL, respectively, and the estimated $L_{50}$ was $35.9 \mathrm{~cm}$ TL for females $(r=0.98 ; P<0.0001)$ and $28.5 \mathrm{~cm}$ TL for males $(r=0.92 ; P<0.0001)$ (Fig. 4).

\section{Reproductive abnormalities}

The reproductive abnormalities detected in forkbeard gonads can be categorized as mosaic intersex specimens, follicular cysts, and early mature males.

Only one mosaic intersex specimen was detected in May 2011 (36.6 cm TL). Macroscopically, this gonad had an immature female aspect with a round shape and a whitish colour. From the histological examination of the gonad, it was possible to identify that the mosaic intersex was formed by an external ovarian wall which surrounded an immature testicular tissue (with only $\mathrm{Sg}$ present) with some PG oocytes embedded on it (Fig. 1d).

Follicular cysts are resultant from an abnormal atretic process in which the chorion does not break and the follicle envelope develops into a cyst (Fig. 1e). In the forkbeard, these cystic structures were observed across all maturity phases and were randomly distributed in the gonad. Mature females from all length classes (31.9$66.6 \mathrm{~cm} \mathrm{TL})$ presented these cysts. Cyst prevalence (percentage of females with ovarian cysts relative to 





Table 1 Oocyte development stages of forkbeard, Phycis phycis

\begin{tabular}{|c|c|c|}
\hline Oocyte development stage & Description & Diameter $(\mu \mathrm{m})$ \\
\hline Primary growth (PG) & $\begin{array}{l}\text { Polyhedral with a large nucleus, where several nucleoli can } \\
\text { easily be observed }\end{array}$ & $22.1-94.7(59.0 \pm 14.8)$ \\
\hline Cortical alveolar (CA) & Cortical alveoli and lipids appear in the cytoplasm & $94.16-191.5(113.7 \pm 14.0)$ \\
\hline Primary vitellogenic (Vtg1) & Appearance of small granules of yolk around the nucleus & $119.4-247.1(160.3 \pm 22.3)$ \\
\hline Secondary vitellogenic (Vtg2) & Larger yolk globules throughout the cytoplasm & $183.1-283.3(219.2 \pm 20.8)$ \\
\hline Tertiary vitellogenic (Vtg3) & $\begin{array}{l}\text { Large yolk globules fill the cytoplasm; oil droplets surround } \\
\text { the nucleus }\end{array}$ & $243.3-402.0(331.0 \pm 34.6)$ \\
\hline Germinal vesicle migration (GVM) & Germinal vesicle migrates to animal pole & $372.3-526.2(435.1 \pm 35.9)$ \\
\hline $\begin{array}{l}\text { Germinal vesicle breakdown and yolk coalescence (GVBD \& } \\
\text { YC) }\end{array}$ & $\begin{array}{l}\text { Germinal vesicle membrane breaks down; yolk globules } \\
\text { become hydrated }\end{array}$ & $416.4-637.0(510.8 \pm 56.2)$ \\
\hline Hydrated (H) & Homogeneous appearance; oocytes ready to be released & $544.0-802.3(639.0 \pm 44.5)$ \\
\hline
\end{tabular}

A brief description of each oocyte stage, its range size, and mean and standard deviation (in brackets) are given

Table 2 Male cells development stages of forkbeard, Phycis phycis

\begin{tabular}{llc}
\hline Spermatogenic stage & Description & Diameter ( $\boldsymbol{\mu m})$ \\
\hline Spermatogonia (Sg) & $\begin{array}{c}\text { Appear single or in groups; round shape with a conspicuous cytoplasm and a prominent } \\
\text { central nucleus }\end{array}$ & $6.44-9.42(7.96 \pm 0.49)$ \\
Primary spermatocytes $(\mathrm{Sc} 1)$ & Always appear enclosed in cysts; smaller than Sg & $3.64-5.77(4.63 \pm 0.34)$ \\
Secondary spermatocytes (Sc2) & Similar to Sc1 but smaller & $2.53-3.96(3.28 \pm 0.26)$ \\
Spermatids (St) & Smaller than Sc2 but still found enclosed in cysts & $1.54-2.94(2.14 \pm 0.19)$ \\
Spermatozoa (Sz) & Similar to St but with cilia; enclosed in cysts or free in the lumen & $1.36-2.04(1.73 \pm 0.13)$ \\
\hline
\end{tabular}

A brief description of each cell stage, its range size, and mean and standard deviation (in brackets) are given

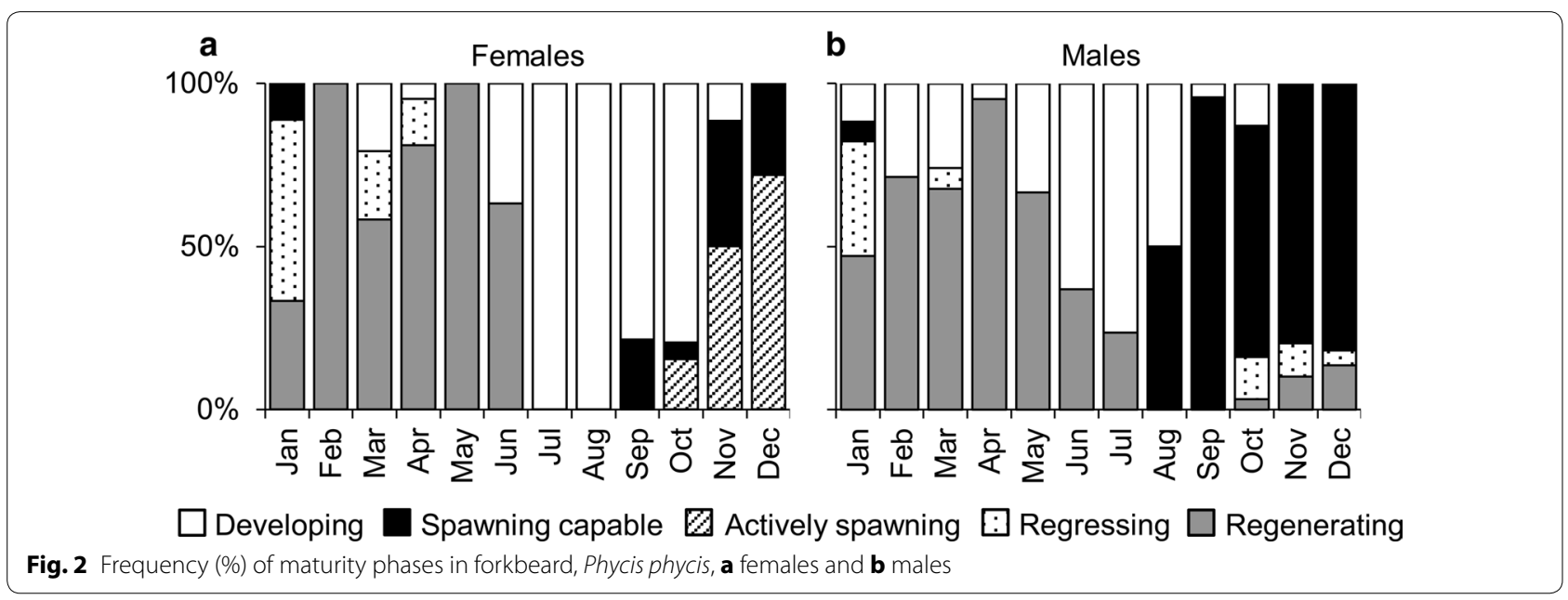

the total number of sampled mature females [12]), in a total of $15.4 \%$, showed three peaks during the year, with the first peak in January (31\%), the second one in April (24\%), and the last one in August (24\%). Minimum values were recorded in September and October (7 \%). Prevalence of these structures was higher in RE females $(66.7 \%)$ and reached lower values in $D$ and $R$ females $(\sim 10 \%)$. Cyst prevalence increased significantly with female TL following a linear relationship (GLM: $r=0.76, P<0.0001)$.

Although males $L_{50}$ has been estimated as $28.5 \mathrm{~cm} \mathrm{TL}$, 7 males with 15.5-23.9 cm TL (sampled between October and December) were classified as mature since in histological sections of their testes it was possible to observe 

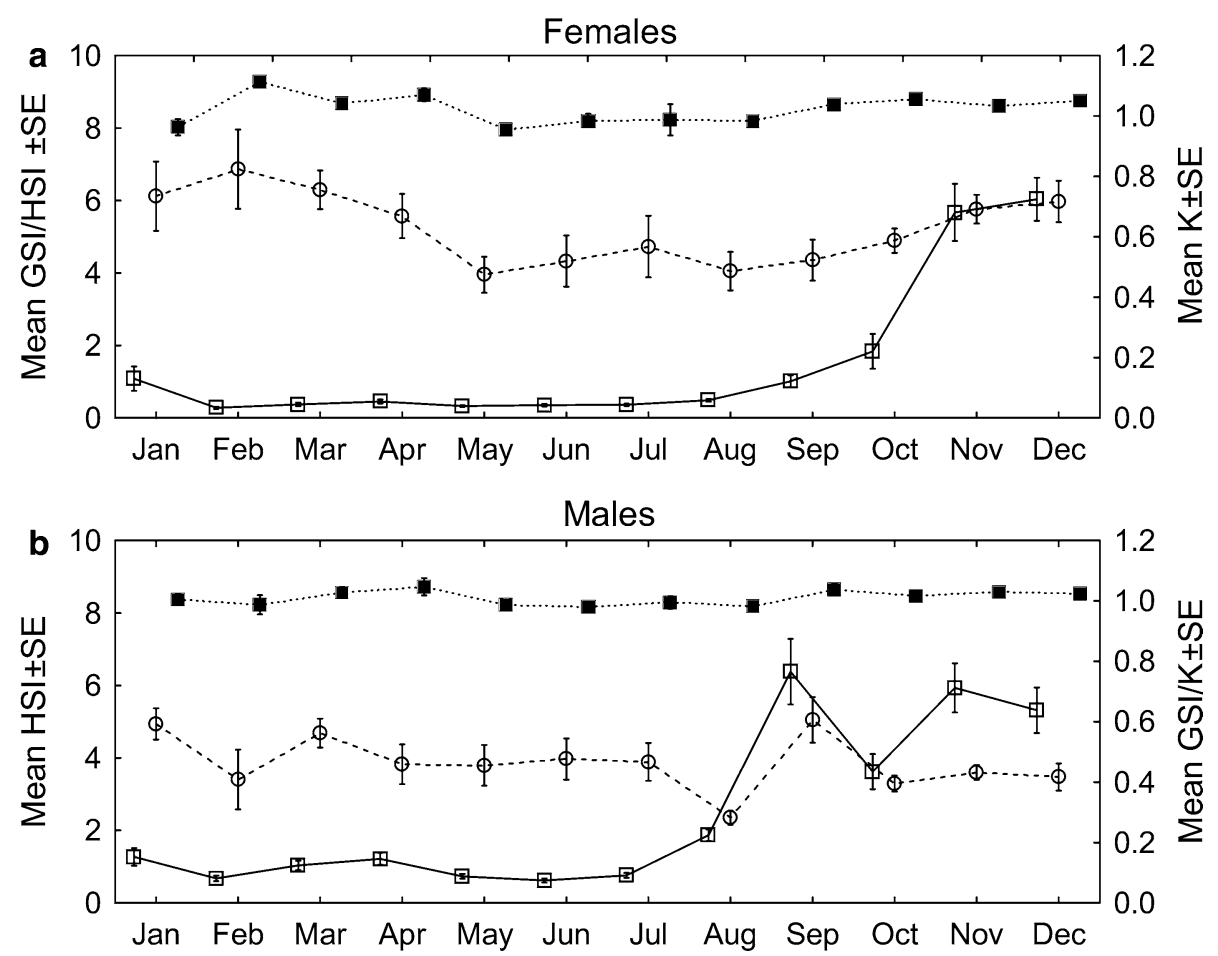

Fig. 3 Monthly variation of the mean and standard error of gonadosomatic index (GSI, empty squares), hepatosomatic index (HSI, empty circles), and Fulton's condition factor ( $K$, black squares) for forkbeard, Phycis phycis, a females and $\mathbf{b}$ males

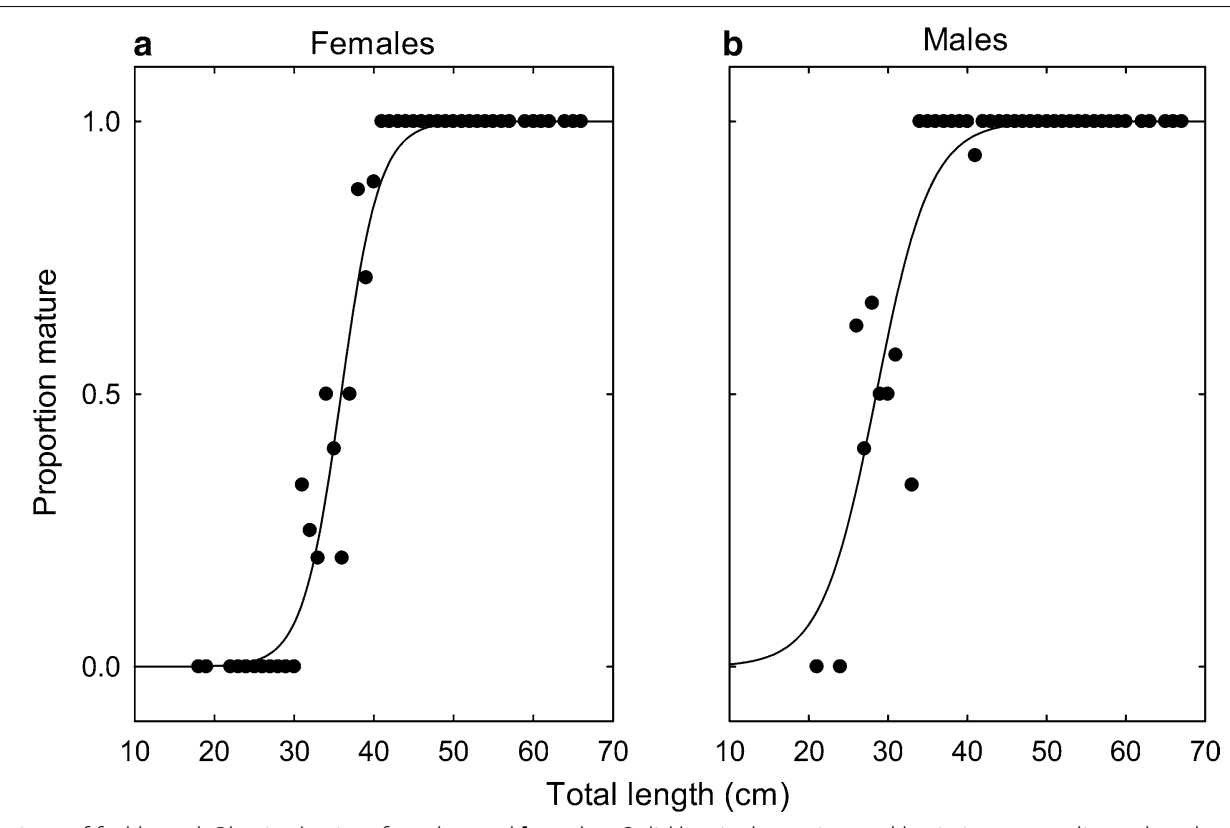

Fig. 4 Maturity ogives of forkbeard, Phycis phycis, a females and $\mathbf{b}$ males. Solid line is the estimated logistic curve adjusted to the observed proportion of mature specimens 
an active spermatogenesis with $\mathrm{Sz}$ in lumen and sperm ducts.

\section{Fecundity}

Forkbeard fecundity type was evaluated under the four criteria stated in "Methods" section. A hiatus between primary and secondary growth oocytes was observed (Fig. 5), indicating a discontinuous oocyte recruitment where the standing stock of oocytes is well defined throughout the spawning season. Regarding the second and third lines of evidence, secondary growth oocytes $(\geq C A)$ were analysed. A significant increase in the mean diameter of secondary growth oocytes throughout the spawning season was found (ANOVA: $P=0.012$ ), namely between the periods $1-15$ Oct and $16-30 \mathrm{Nov}$, and 1-15 Dec and 16-31 Dec (LSD test: $P<0.05$ ) (Fig. 6a). A non-significant decreasing trend in the number of secondary growth oocytes throughout the spawning season was observed (PERMANOVA: $P=0.300$ ) (Fig. $6 \mathrm{~b}$ ). The relative intensity of $\alpha$-atresia in forkbeard ovaries was low throughout the spawning season, with monthly mean values varying between 4.9 and $9.5 \%$ (7.5 $\pm 3.6 \%$, mean $\pm \mathrm{SD}$ ), and no significant differences between months were found (ANOVA: $P=0.298$ ).

Forkbeard potential annual fecundity ranged between 633,228 and 5823,090 oocytes per female and total annual fecundity (TAF) between 572,921 and 5,823,090 oocytes per female. No significant differences were found between the potential annual fecundity and the total annual fecundity estimates ( $t$ test: $P=0.980$ ), which indicates that fecundity down-regulation by means of atresia in forkbeard ovaries was low. A significant power relation of TAF with TL and GW was observed $(P<0.0001)$ (Fig. 7). Relative annual fecundity varied between 628 (in September, female with $43.0 \mathrm{~cm}$ TL and $912.59 \mathrm{~g}$ GW) and 4282 (in December, female with $51.9 \mathrm{~cm}$ TL and $1359.81 \mathrm{~g} \mathrm{GW}$ ) oocytes $\mathrm{g}^{-1} \mathrm{GW}$, with a mean of $1833 \pm 857$ oocytes $\mathrm{g}^{-1} \mathrm{GW}$.

\section{Skipped spawning}

Not all females sampled during the spawning season (with $\mathrm{TL}>L_{50}$ ) were physiologically able to spawn (SC and AS maturity phases). Non-reproductive females that interrupted the normal reproductive cycle presented three types of ovaries: (1) mature ovaries in which oocyte development began but was interrupted before vitellogenesis was complete, and early vitellogenic oocytes were reabsorbed via atresia (Fig. 1f); (2) ovaries that did not produce secondary growth oocytes, maintaining PG oocytes throughout the year and until the next season (Fig. 1g); and (3) ovaries that maintained CA oocytes throughout the year and until the next season (Fig. 1h). The proportion of females considered as skipped spawners was $36.1 \%(37.0-54.1 \mathrm{~cm} \mathrm{TL})$. These females were easily recognized by their significantly lower GSI $(t$ test: $P<0.0001$ ) (Fig. 8a, b) and HSI ( $t$ test: $P=0.040$ ) (Fig. 8c, d) in comparison with those of reproductive ones (SC and AS females). No significant differences ( $t$ test:
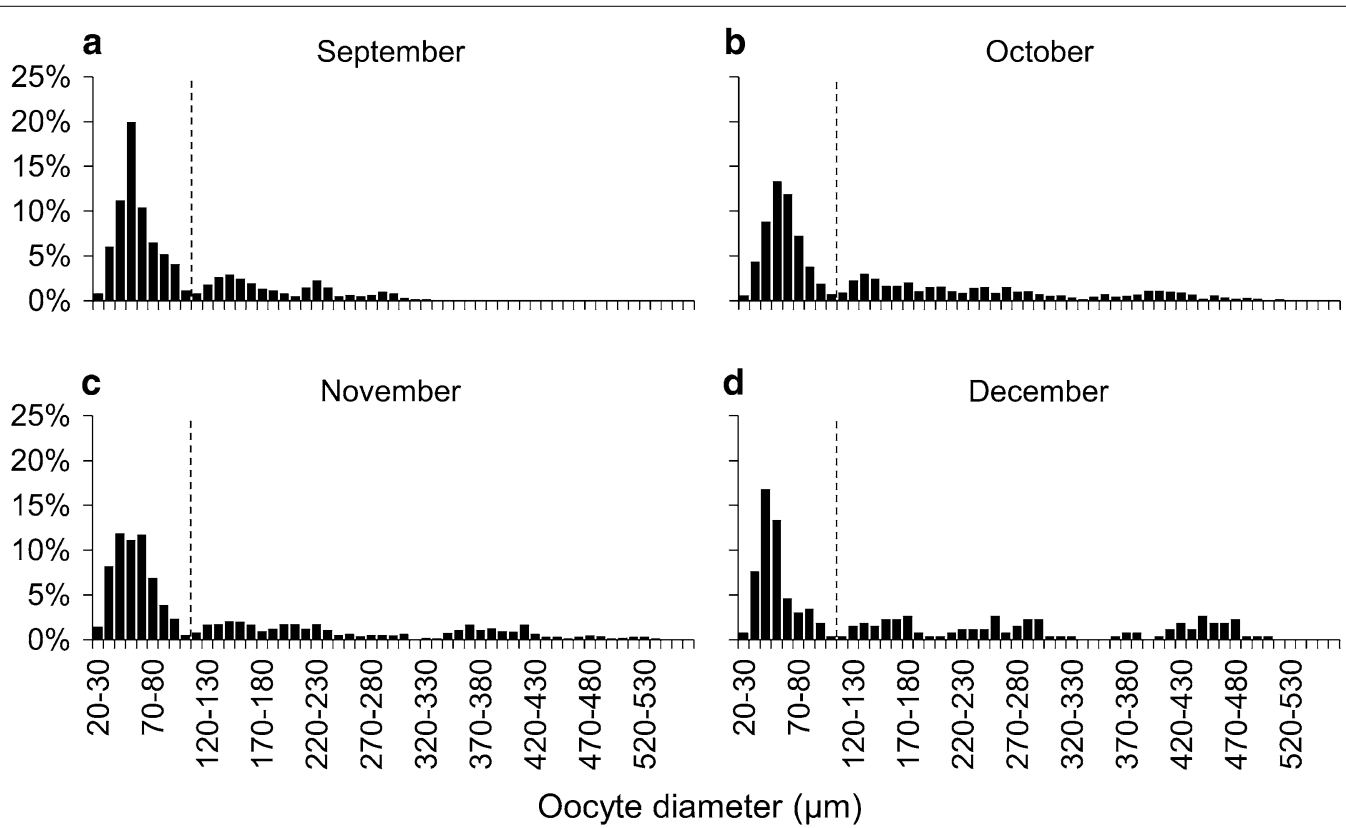

Fig. 5 Forkbeard, Phycis phycis, oocyte size frequency (\%) distribution throughout the spawning season: a September, b October, c November, and d December. Vertical dashed line indicates transition from primary to secondary growth oocytes 

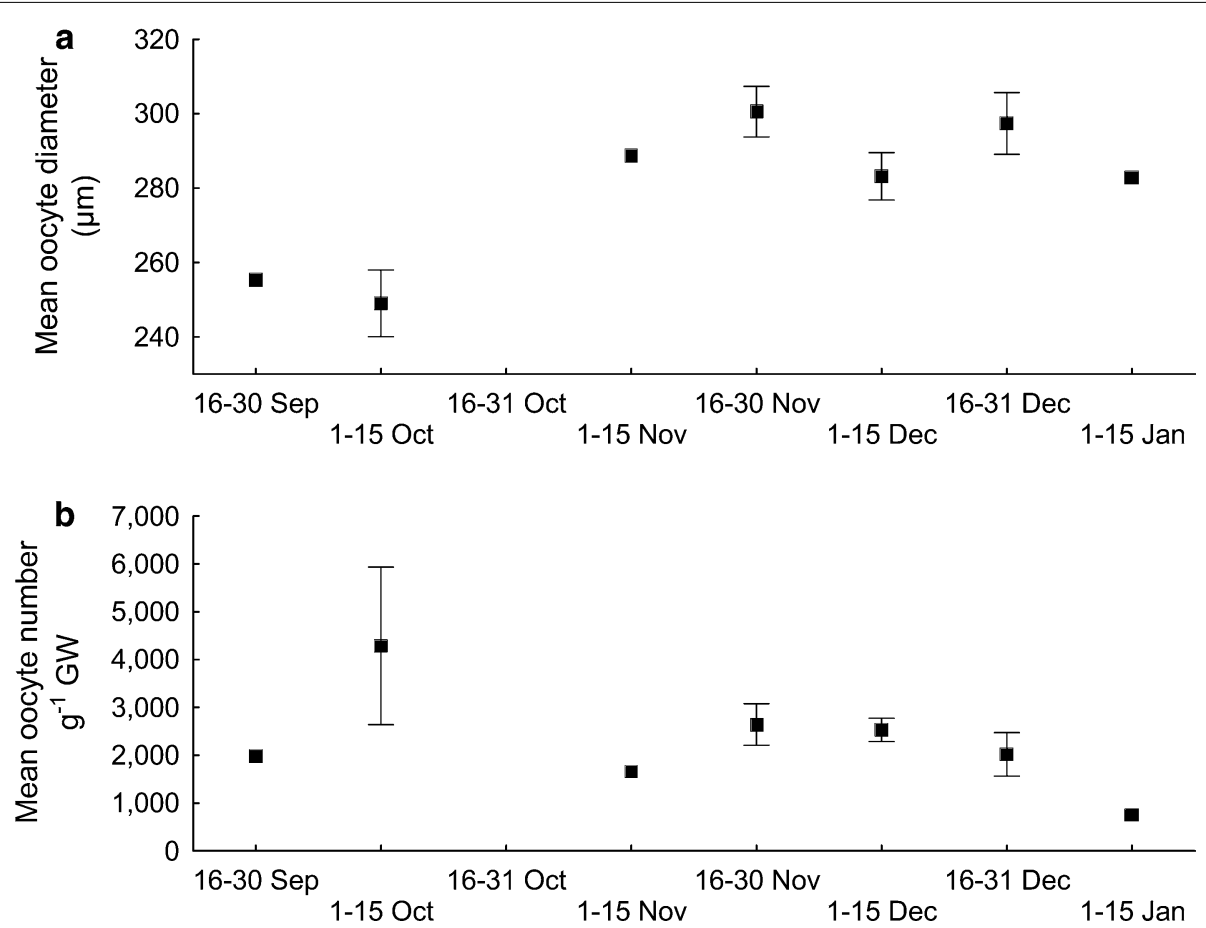

Fig. 6 Mean a oocyte diameter and $\mathbf{b}$ oocyte number ( $\mathrm{g}^{-1}$ gutted weight) of secondary growth oocytes in mature ovaries of forkbeard, Phycis phycis, throughout the spawning season

$P=0.571)$ were found in $K$ between reproductive and non-reproductive females (Fig. 8e, f).

\section{Discussion}

The main purpose of a reproductive strategy is to maximize reproductively active offspring in relation to available energy and parental life expectancy [66]. This study indicates that the forkbeard is an iteroparous and gonochoristic species, which shows no sexual dimorphism, has external fertilization without parental care, presents a group-synchronous ovary development, is a batch spawner, and possesses determinate fecundity.

The gonad structure is similar to the one found in most teleost species, with oocytes randomly distributed in the ovary and with no differences in the oocyte frequency distribution between the left and right ovaries and different regions of each ovary. Testes are constituted by seminiferous tubules bearing cysts with synchronous development of the sexual cells.

In Portuguese continental waters, the forkbeard has a relatively short spawning season occurring from September to early January. In the present study, this season was defined as the period between appearance of the first active females with yolked oocytes, not necessarily spawning, until the last active females sampled [32]. In this study, the spawning season was corroborated by the
GSI results. Similar spawning seasons were obtained for the Azores [69] and the Adriatic Sea [18].

Length at first maturity $\left(L_{50}\right)$ was estimated, based on histological observation, as $35.9 \mathrm{~cm}$ TL for females and $28.5 \mathrm{~cm}$ TL for males. Based on the previous age determination results for this species [75], these lengths correspond to ages of 4.2 years for females and 2.5 years for males. The lengths at first maturity estimated in this study were different from the estimates of 31 and $33 \mathrm{~cm}$ TL obtained for females and males, respectively, of the forkbeard from the Adriatic Sea [18], and 41 and $36 \mathrm{~cm}$ TL for females and males (respectively) from the Azores [69], which were both based on macroscopic observation. Differences between histological and macroscopic ogives normally arise from the difficulty of distinguishing macroscopically immature from regenerating fishes, and maturity phase assignment by histological staging gives less biased estimates of maturity [27]. However, size at maturity is known to be a highly plastic parameter that changes under external pressure, and so the observed differences may thus be the consequence of population changes [73].

The forkbeard presented some reproductive abnormalities. Although males attain sexual maturity at $28.5 \mathrm{~cm} \mathrm{TL}$ (corresponding to 2-3 years of age), few males matured precociously and were considered as early 


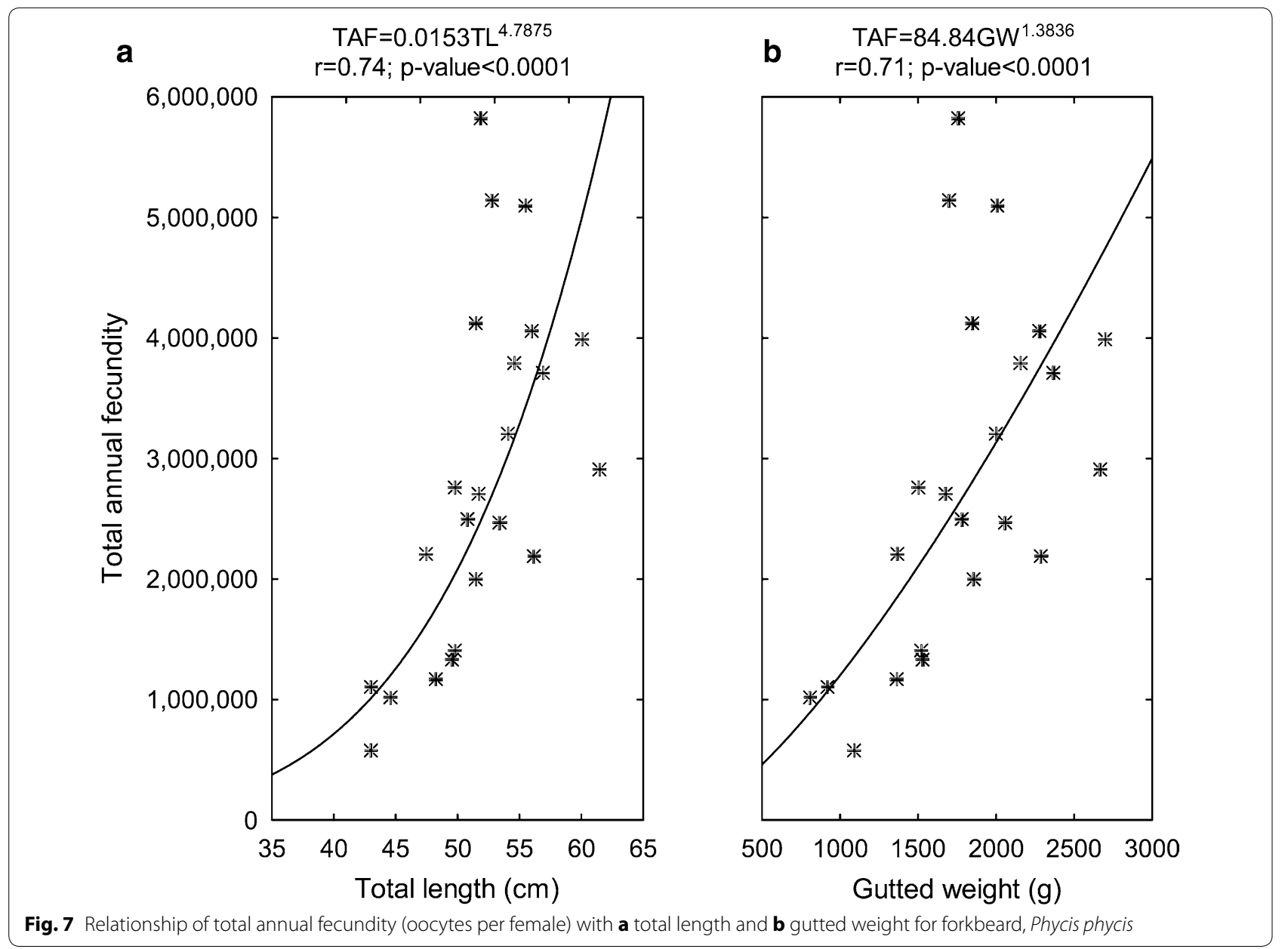

maturing males. The length, and consequently the age, of first maturity is influenced by both genetic [67] and environmental factors [77]. However, it is recognized that hormonal intervention can induce spermatogenesis, overriding the genetic basis of early maturation [40, 81]. Early testicular maturity is quite common in fish and has been studied in salmons (e.g. [15, 39], and striped bass Morone saxatilis (Walbaum, 1792) [23]. In many fish species, early testicular maturation can also be a result of the natural plasticity of length at first maturity [57], a phenomenon that does not involve an alternative reproductive strategy [23].

Other reproductive abnormalities detected in forkbeard gonads were the mosaic intersex and follicular cysts in ovaries. The intersex condition is well described for gonads of several wild gonochoristic teleost fish species inhabiting freshwater habitats (e.g. whitefish Coregonus sp. [3]; and trouts Oncorhynchus clarkii (Richardson, 1836) and Salvelinus fontinalis (Mitchill, 1814) [68]). Although rare in marine wild fishes, some cases of mosaic intersex have been reported (e.g. dab Limanda limanda
(Linnaeus, 1758) [71]; and eelpout Zoarces viviparus (Linnaeus, 1758) [17]. The present study refers the first case of intersex in the forkbeard. Intersexuality can result from genetic mutations, diseases caused by parasite infections, abrupt temperature changes, environmental contamination, endocrine disruptors (xenoestrogens), or endocrine abnormalities $[3,68]$, and may cause a reduction in the reproductive capability of intersex fish [30]. The implications of this reduced reproductive capacity of a proportion of fish in a given population are unknown but could cause a decrease in the population recruitment [22]. Regarding follicular cysts, they result from an abnormal atretic process in which the chorion does not break and the follicle envelope develops into a cyst [12]. To date, the process by which these cysts are formed is still unknown, but one hypothesis is that when the oocyte begins to degenerate due to atresia it may be recognized as a foreign or damaged cell, causing an immune reaction that leads to an inflammatory process [12]. The suggested causes are as follows: female physiological condition [35, 61], stressing factors (e.g. temperature and $\mathrm{pH}$ ) [41], food 


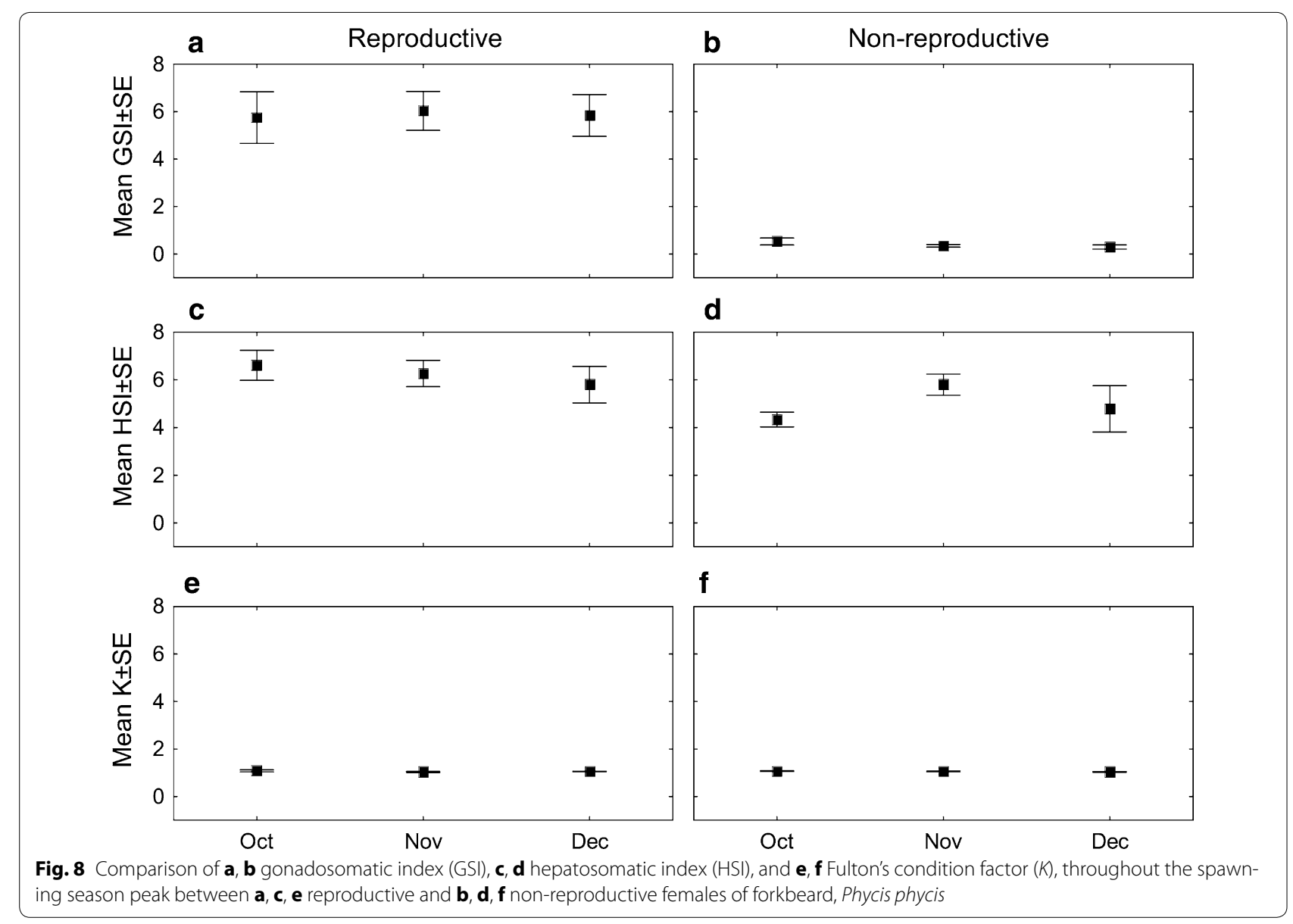

availability [70], parasitism or disease [9], intra-specific competition [59], and anthropogenic effects [52]. Cysts can remain in the ovary for long periods of time, affecting female reproductive potential in future spawning seasons, and have already been reported as sporadic in several marine fish species such as Atlantic cod Gadus morhua Linnaeus, 1758 [12, 62, 80], European hake [12], and blue marlin Makaira nigricans Lacepède, 1802 [8], and as a reproductive strategy in salema Sarpa salpa (Linnaeus, 1758) [53].

Like other gadiform species (e.g. Atlantic cod [1, 28]; and haddock Melanogrammus aeglefinus (Linnaeus, 1758) [1, 74]), the forkbeard is a batch spawner with a group-synchronous ovarian development organization. In these species, at least two cohorts of oocytes can be recognized: one of larger oocytes and another of smaller ones. This type of ovaries could be found in iteroparous species with a relatively short spawning season and where the yolk accumulation mostly depends on body reserves [49]. In batch spawners species, only a portion of advanced yolked oocytes is spawned in each batch through the hydration and ovulation processes. Most of commercially important species from temperate Atlantic waters are batch spawners (independently of their type of fecundity being determinate or indeterminate), although the number of batches varies considerably depending on the species (e.g. Atlantic sardine Sardina pilchardus (Walbaum, 1792) [51, 60]; horse mackerel Trachurus trachurus (Linnaeus, 1758) [33]; Atlantic mackerel Scomber scombrus Linnaeus, 1758 [58]; and European hake [45, $48])$. Batch spawning can be considered as a strategy to increase the survival probability of offspring since the release of oocytes occurs over a longer time period [38]. However, it can also be seen as a need of higher fecund species due to a physical limitation, when the hydration of oocytes takes place and the increase in ovaries volume expands the abdominal cavity [16].

The present study was the first one to analyse all lines of evidence $[27,20,49]$ to access forkbeard fecundity type. A hiatus between the primary and secondary growth oocytes was detected. This has been shown to correlate with a determinate fecundity [20], suggesting that forkbeard has such king of strategy. Secondary growth oocytes throughout the spawning season presented a 
statistical significant increase in their mean diameter and decrease in their number (although not statistically significant). These results also suggest determinate fecundity as no new secondary growth oocytes are recruited to replace those that have been shed during the spawning season. If a species has an indeterminate fecundity, it was expected that the size of secondary growth oocytes did not increase (it might remain constant or decrease) over the spawning season due to the recruitment of new oocytes (de novo vitellogenesis) [49]. The knowledge of the type of fecundity contributes to a better understanding of the reproductive potential and is essential for the estimation of the relative annual fecundity.

Atresia is a potential source of error (although atretic oocytes can be easily identified and estimated histologically) for fecundity estimates [27, 11] and can influence the number of oocytes to be released in the coming spawning season as well as the development rate of the next oocyte generation [55]. Several methods with different accuracy levels exist to estimate the intensity of atresia in an ovary [36]. However, in the method used in the present study (counting oocytes of different diameters in histological sections), the degree of bias is inversely proportional to oocyte diameter, and thus, atresia could be underestimated but not overestimated since atretic oocytes are smaller than non-atretic ones, either because of size-specific selection [79], shrinkage, or a combination of both [37]. In fish with determinate fecundity, the intensity of atresia rarely is generalized and, if present, is distributed sparsely throughout the spawning season. Moreover, low levels of atresia usually characterize determinate spawners and do not seem to have a greater effect on the potential fecundity [27]. In the present study, the intensity of atresia was low throughout the spawning season, reinforcing the determinate fecundity type of forkbeard.

It is known that short spawning seasons are typical of species with determinate fecundity (e.g. Atlantic cod [72]; black scabbardfish Aphanopus carbo Lowe, 1839 [14, 50]; and European seabass Dicentrarchus labrax (Linnaeus, 1758) [43]), and it is assumed that species with determinate fecundity are strongly associated with capital breeding behaviour [44]. In determinate species, the reproductive investment is heavily dependent on the feeding season prior to the major yolk production that takes place during vitellogenesis [5]; however, batch spawning can reduce the energy initially required for spawning [44]. The forkbeard seems to have a mixedbreeding strategy, since feeding is common during late vitellogenesis but may also take place during parts of the spawning season (Ana R. Vieira 2012, personal observation). Therefore, fecundity of the forkbeard is probably influenced by the fish condition both at the onset of vitellogenesis and during subsequent oocyte maturation and spawning.

For determinate species, the time of sampling is an important key for potential fecundity estimates, since they will be biased if the sampling is done either too early or too late in the spawning season. If sampling is done too early, the secondary growth oocytes may not have matured enough to be completely separated from the primary growth ones, and consequently, fecundity estimates may be imprecise or biased. If it is done too late, spawning will have begun, the stock of secondary growth oocytes will have been reduced, and the potential fecundity will be underestimated [26]. In the present study, this sampling problem was avoided by confirming the presence of POF and excluding such ovaries from the fecundity estimates. Fecundity estimates are essential to calculate spawning stock biomass [19]. The forkbeard showed a relative annual fecundity ranging from 628 to 4282 oocytes $\mathrm{g}^{-1} \mathrm{GW}$. Relative fecundity estimates of the same order of magnitude were found for other gadiform species (e.g. Atlantic cod, Gadus morhua [4]; and European hake, Merluccius merluccius $[45,48])$.

The presence of non-reproductive females of the forkbeard in Portuguese continental waters may indicate the occurrence of skipped spawning. This process is a plastic response of fishes to low levels of stored energy or unsuitable environmental conditions which lead to sacrificing egg production until the subsequent year [65]. According to the classification proposed by Rideout et al. [64], forkbeard presented three types of skipped spawning: reabsorbing-Vtg, when mature females in the beginning of oocyte development suspend the process before maturation is complete, reabsorbing all vitellogenic oocytes via follicular atresia; resting-PG, when mature females do not produce secondary growth oocytes, maintaining all oocytes in various stages of PG throughout the year; and resting- $\mathrm{CA}$, when mature females maintain all oocytes in PG and CA stages throughout the year. It is known that non-reproductive individuals tend to be in poorer condition and have a lower hepatosomatic index than fish that are successfully ripening [61]. It is possible that the liver plays an important role in the success of forkbeard maturation based on the difference found in the HSI between non-reproductive and reproductive females. Liver could be the trigger and primary source of energy, with muscle being the secondary source. This could explain the absence of differences in the Fulton's condition factor found during the spawning season between non-reproductive and reproductive females. In fact, the condition indices are likely much more meaningful predictors of egg production in capital breeders than in income breeders [34]. However, and according to Jørgensen et al. [31], poor individual condition at the 
beginning of a spawning season can be either a cause or an effect of skipped spawning and if spawning is skipped then the best option should be to give priority to somatic growth, keeping energy reserves at a moderate level and resulting in a low condition factor. This poor condition would then be an effect of skipped spawning and thus hard to separate from poor condition stemming from low food availability, which could lead to skipped spawning. In the forkbeard, the percentage of non-reproductive females attained $36.1 \%$, which means that, in the future, it will be important to analyse the extent of skipped spawning in order to prevent an overestimate of the population's reproductive potential that could lead to erroneous assessment estimates with possible consequences for management purposes. Failure to account for the proportion of females that are actually skipping spawning could result in an overestimation of spawning stock biomass and ineffective management advice.

\section{Authors' contributions}

ARV carried out the sampling, conceived, designed and performed all the experiments of this study, analysed the data and wrote the manuscript. VS helped in the sampling and in the conception and design of the experiments. AN helped in the sampling and in the data analysis. RBP helped in sampling. LSG helped in the conception of this study and contributed with reagents and materials. All authors read and approved the final manuscript.

\section{Author details}

${ }^{1}$ MARE - Marine and Environmental Sciences Centre, Faculdade de Ciências, Universidade de Lisboa, Campo Grande, 1749-016 Lisbon, Portugal. ${ }^{2}$ Departamento de Biologia Animal, Faculdade de Ciências, Universidade de Lisboa, Campo Grande, 1749-016 Lisbon, Portugal.

\section{Acknowledgements}

The authors would like to thank Pedro Gomes and the crew of the trawler "Sagittarius" by providing smaller specimens of forkbeard used in this study. This study was partially support by the project PROMAR 31-03-05-FEP-8, and by Fundação para a Ciência e a Tecnologia (FCT), through the grants attributed to Ana Rita Vieira (SFRH/BD/73506/2010), Vera Sequeira (SFRH/ BPD/70200/2010), Ana Neves (SFRH/BD/92769/2013), and Rafaela Barros Paiva (SFRH/BD/80268/2011).

\section{Competing interests}

The authors declare that they have no competing interests.

Received: 1 July 2015 Accepted: 7 December 2015

Published online: 20 April 2016

\section{References}

1. Alonso-Fernández A, Vallejo AC, Saborido-Rey F, Murua H, Trippel EA. Fecundity estimation of Atlantic cod (Gadus morhua) and haddock (Melanogrammus aeglefinus) of Georges Bank: application of the autodiametric method. Fish Res. 2009;99:47-54. doi:10.1016/j.fishres.2009.04.011.

2. Anderson MJ. A new method for non-parametric multivariate analysis of variance. Austral Ecol. 2001;26:32-46. doi:10.1111/j.1442-9993.2001.01070.

3. Bernet $D$, Wahli T, Kueng $C$, Segner H. Frequent and unexplained gonadal abnormalities in whitefish (central alpine Coregonus sp.) from an alpine oligotrophic lake in Switzerland. Dis Aquat Org. 2004;61:137-48. doi:10.3354/dao061137.

4. Bleil M, Oeberst R. The potential fecundity of cod in the Baltic Sea from 1993 to 1999. J Appl Ichthyol. 2005;21:19-27. doi:10.1111/j.1439-0426.2004.00595.x.
5. Boulcott P, Wright PJ. Critical timing for reproductive allocation in a capital breeder: evidence from sandeels. Aquat Biol. 2008;3:31-40. doi:10.3354/ ab00063.

6. Bray JR, Curtis JT. An ordination of the upland forest communities of Southern Wisconsin. Ecol Monogr. 1957;27:325-49. doi:10.2307/1942268.

7. Brown-Peterson NJ, Wyanski DM, Saborido-Rey F, Macewicz BJ, LowerreBarbieri SK. A standardized terminology for describing reproductive development in fishes. Mar Coast Fish. 2011;3:52-70. doi:10.1080/194251 20.2011.555724.

8. Brown-Peterson NJ, Franks JS, Comyns BH, McDowell JR. Do blue marlin spawn in the Northern Gulf of Mexico? In: Proceedings of the 60th Gulf and Caribbean Fisheries Institute; 2008. p. 372-8.

9. Clarke LM, Dove ADM, Conover DO. Prevalence, intensity, and effect of a nematode (Philometra saltatrix) in the ovaries of bluefish (Pomatomus saltatrix). Fish Bull. 2006;104:118-24.

10. Cohen DM, Inada T, Iwamoto T, Scialabba N. FAO species catalogue, vol 10. Gadiform fishes of the world (Order Gadiformes). An annotated and illustrated catalogue of cods, hakes, grenadiers and other gadiform fishes known to date. FAO Fisheries synopsis no. 125. Rome: FAO; 1990.

11. Cooper DW, Pearson KE, Gunderson DR. Fecundity of shortspine thornyhead (Sebastolobus alascanus) and longspine thornyhead (S. altivelis) (Scorpaenidae) from the northeastern Pacific Ocean, determined by stereological and gravimetric techniques. Fish Bull. 2005;103:15-22.

12. Domínguez-Petit R, Alonso-Fernández A, Saborido-Rey F. Incidence and significance of cystic structures in the ovaries of gadoid fish. Sci Mar. 2011;75:359-68. doi:10.3989/scimar.2011.75n2359.

13. FAO. FAO yearbook-fishery and aquaculture statistics 2012. 2012. http:// www.fao.org/fishery/publications/yearbooks/en. Accessed 23 Jan 2015.

14. Figueiredo I, Bordalo-Machado P, Reis S, Sena-Carvalho D, Blasdale T, Newton A, Gordo LS. Observations on the reproductive cycle of the black scabbardfish (Aphanopus carbo Lowe, 1839) in the NE Atlantic. ICES J Mar Sci. 2003;60:774-9. doi:10.1016/s1054-3139(03)00064-x.

15. Ford M, Murdoch A, Howard S. Early male maturity explains a negative correlation in reproductive success between hatchery-spawned salmon and their naturally spawning progeny. Conserv Lett. 2012;5:450-8. doi:10.1111/j.1755-263X.2012.00261.X.

16. Fordham BSE, Trippel EA. Feeding behaviour of cod (Gadus morhua) in relation to spawning. J Appl Ichthyol. 1999;15:1-9. doi:10.1046/j.1439-0426.1999.00098.x.

17. Gercken J, Sordyl H. Intersex in feral marine and freshwater fish from northeastern Germany. Mar Environ Res. 2002;54:651-5. doi:10.1016/ S0141-1136(02)00156-3.

18. Glavić K, Dobroslavić T, Bartulović V, Matić-Skoko S, Glamuzina B. The reproductive biology of forkbeard, Phycis phycis (Linnaeus, 1766) (Phycidae) in the Adriatic Sea (Croatia). Turk J Fish Aquat Sci. 2014;14:165-71. doi:10.4194/1303-2712-v14_1_18.

19. Gordo LS, Costa A, Abaunza P, Lucio P, Eltink ATGW, Figueiredo I. Determinate versus indeterminate fecundity in horse mackerel. Fish Res. 2008;89:181-5. doi:10.1016/j.fishres.2007.09.024.

20. Greer-Walker M, Witthames PR, Bautista-de-los-Santos JI. Is the fecundity of the Atlantic mackerel (Scomber scombrus: Scombridae) determinate? Sarsia. 1994;79:12-26. doi:10.1080/00364827.1994.10413543.

21. Grier HJ, Uribe-Aranzábal MC. The testis and spermatogenesis in teleosts. In: Jamieson BGM, editor. Reproductive biology and phylogeny of fishes (agnathans and bony fishes). Enfield: Science Publishers; 2009. p. 119-42.

22. Harris $C A$, et al. The consequences of feminization in breeding groups of wild fish. Environ Health Perspect. 2011;119:306-11. doi:10.1289/ ehp. 1002555.

23. Hassin $\mathrm{S}$, Claire M, Holland $\mathrm{H}$, Zohar Y. Early maturity in the male striped bass, Morone saxatilis: follicle-stimulating hormone and luteinizing hormone gene expression and their regulation by gonadotropin-releasing hormone analogue and testosterone. Biol Reprod. 2000;63:1691-7. doi:10.1095/biolreprod63.6.1691.

24. Hilborn R, Walters CJ. Quantitative fisheries stock assessment: choice, dynamics and uncertainty. New York: Chapman \& Hall; 1992. p. 372-8.

25. Hunter JR, Macewicz BJ. Rates of atresia in the ovary of captive and wild northern anchovy, Engraulis mordax. Fish Bull. 1985;83:119-36.

26. Hunter JR, Macewicz BJ, Kimbrell CA. Fecundity and other aspects of the reproduction of sablefish, Anoplopoma fimbria, in central California waters. CalCOFI Rep. 1989;30:61-72. 
27. Hunter JR, Macewicz BJ, Lo NCH, Kimbrell CA. Fecundity, spawning, and maturity of female Dover Sole, Microstomus pacificus, with an evaluation of assumptions and precision. Fish Bull. 1992;90:101-28.

28. Hutchings JA, Bishop TD, McGregor-Shaw CR. Spawning behaviour of Atlantic cod, Gadus morhua: evidence of mate competition and mate choice in a broadcast spawner. Can J Fish Aquat Sci. 1999;56:97-104. doi:10.1139/f98-216.

29. INE. Statistical data for fisheries 2001-2013. 2014. http://www.ine.pt/ xportal/xmain?xpid=INE\&xpgid=ine_base_dados. Accessed 8 July 2014

30. Jobling $S$, et al. Wild intersex roach (Rutilus rutilus) have reduced fertility. Biol Reprod. 2002;67:515-24. doi:10.1095/biolreprod67.2.515.

31. Jørgensen C, Ernande B, Fiksen $\varnothing$, Dieckmann U. The logic of skipped spawning in fish. Can J Fish Aquat Sci. 2006;63:200-11. doi:10.1139/f05-210.

32. Karlou-Riga C, Economidis PS. Ovarian atretic rates and sexual maturity of European horse mackerel, Trachurus trachurus (L.), in the Saronikos Gulf (Greece). Fish Bull. 1996;94:66-76.

33. Karlou-Riga C, Economidis PS. Spawning frequency and batch fecundity of horse mackerel, Trachurus trachurus (L.), in the Saronikos Gulf (Greece). J Appl Ichthyol. 1997;13:97-104. doi:10.1111/j.1439-0426.1997.tb00108.x.

34. Kjesbu OS. Applied fish reproductive biology: contribution of individual reproductive potential to recruitment and fisheries management. In: Jakobsen T, Fogarty MJ, Megrey BA, Moksness E, editors. Fish reproductive biology: implications for assessment and management. Oxford: WileyBlackwell; 2009. p. 293-332. doi:10.1002/9781444312133.ch8.

35. Kjesbu OS, Klungsoyr J, Kryvi H, Witthames PR, Walker MG. Fecundity, atresia, and egg size of captive Atlantic cod (Gadus morhua) in relation to proximate body composition. Can J Fish Aquat Sci. 1991;48:2333-43.

36. Kjesbu OS, Fonn M, Gonzáles BD, Nilsen T. Stereological calibration of the profile method to quickly estimate atresia levels in fish. Fish Res 2010;104:8-18. doi:10.1016/j.fishres.2010.03.013.

37. Kurita Y, Meierb S, Kjesbu OS. Oocyte growth and fecundity regulation by atresia of Atlantic herring (Clupea harengus) in relation to body condition throughout the maturation cycle. J Sea Res. 2003;49:203-19. doi:10.1016/ s1385-1101(03)00004-2.

38. Lambert TC, Ware DM. Reproductive strategies of demersal and pelagic spawning fish. Can J Fish Aquat Sci. 1984;41:1565-9. doi:10.1139/f84-194.

39. Larsen DA, Beckman BR, Cooper KA. Examining the conflict between smolting and precocious male maturation in spring (stream-type) chinook salmon. Trans Am Fish Soc. 2010;139:564-78. doi:10.1577/t08-209.1.

40. Lee CS, Weber GM, Tamaru CS. Effect of orally-administered 17a-methyltestosterone on spermatogenesis in immature milkfish, Chanos chanos Forsskal. J Fish Biol. 1986;29:567-72. doi:10.1111/j.1095-8649.1986.tb04973.x.

41. Linares-Casenave J, Van Eenennaam JP, Doroshov SI. Ultrastructural and histological observations on temperature-induced follicular ovarian atresia in the white sturgeon. J Appl Ichthyol. 2002;18:382-90. doi:10.1046/j.1439-0426.2002.00369.x.

42. Lowerre-Barbieri SK, Brown-Peterson NJ, Murua H, Tomkiewicz J, Wyanski DM, Saborido-Rey F. Emerging issues and methodological advances in fisheries reproductive biology. Mar Coast Fish. 2011;3:32-51. doi:10.1080/ 19425120.2011 .555725$.

43. Mayer I, Shackley SE, Witthames PR. Aspects of the reproductive biology of the bass, Dicentrarchus labrax L. II. Fecundity and pattern of oocyte development. J Fish Biol. 1990;36:141-8. doi:10.1111/j.1095-8649.1990. tb05590.x.

44. McBride RS, et al. Energy acquisition and allocation to egg production in relation to fish reproductive strategies. Fish Fish. 2015;16:23-57. doi:10.1111/faf.12043.

45. Mehault S, Domínguez-Petit R, Cerviño S, Saborido-Rey F. Variability in total egg production and implications for management of the southern stock of European hake. Fish Res. 2010;104:111-22. doi:10.1016/j. fishres.2010.03.019.

46. Morato T, Solà E, Grós MP, Menezes G. Diets of forkbeard (Phycis phycis) and conger eel (Conger conger) off the Azores during Spring of 1996 and 1997. Arquipél Life Mar Sci. 1999;17:51-64.

47. Murua H, Kraus G, Saborido-Rey F, Witthames P, Thorsen A, Junquera S. Procedures to estimate fecundity of marine fish species in relation to their reproductive strategy. J Northwest Atl Fish Sci. 2003;33:33-54.

48. Murua H, Motos L, Lucio P. Reproductive modality and batch fecundity of the European hake (Merluccius merluccius L.) in the Bay of Biscay. CalCOFI Rep. 1998;39:196-203.
49. Murua H, Saborido-Rey F. Female reproductive strategies of marine fish species of the North Atlantic. J Northwest Atl Fish Sci. 2003;33:23-31.

50. Neves A, Vieira AR, Farias I, Figueiredo I, Sequeira V, Gordo LS. Reproductive strategies in black scabbardfish (Aphanopus carbo Lowe, 1839) from the NE Atlantic. Sci Mar. 2009;73:19-31. doi:10.3989/ scimar.2009.73s2019.

51. Nunes C, Silva A, Marques V, Ganias K. Integrating fish size, condition, and population demography in the estimation of Atlantic sardine annual fecundity. Cienc Mar. 2011;37:565-84.

52. Oven LS. Resorption of vitellogenous oocytes as an indicator of the state of the Black Sea fish populations and their environment. J Ichthyol. 2004;44:115-9.

53. Paiva RB, et al. Cystic structures in fish ovaries: more common than we think. The case study of Sarpa salpa (Sparidae). Cybium. 2014;38:158-60.

54. Papaconstantinou C, Caragitsou E. Feeding interaction between two sympatric species Pagrus pagrus and Phycis phycis around Kastellorizo Island (Dodecanese, Greece). Fish Res. 1989;7:329-42. doi:10.1016/0165-7836(89)90065-9.

55. Pavlov DA, NyG E, Novikov GG. Reproductive Dynamics. In: Jakobsen T, Fogarty MJ, Megrey BA, Moksness E, editors. Fish reproductive biology: implications for assessment and management. Oxford: Wiley-Blackwell; 2009. p. 48-90. doi:10.1002/9781444312133.ch2.

56. Pawson MG, Jennings S. A critique of methods for stock identification in marine capture fisheries. Fish Res. 1996;25:203-17. doi:10.1016/0165-7836(95)00441-6.

57. Policansky D. Size, age and demography of metamorphosis and sexual maturation in fishes. Am Zool. 1983;23:57-63. doi:10.1093/icb/23.1.57.

58. Priede IG, Watson JJ. An evaluation of the daily egg production method for estimating biomass of Atlantic mackerel (Scomber scombrus). Bull Mar Sci. 1993;53:891-911.

59. Privalikhin AM. Resorption of developing oocytes as a regulatory mechanism of formation of individual and population fecundity in Walleye Pollock Theragra chalcogramma (Gadidae). J Ichthyol. 2003:43:454-63.

60. Quintanilla LF, Pérez N. Spawning frequency of Sardina pilchardus (Walb.) off the Spanish North Atlantic coast in 1997. Fish Res. 2000;45:73-9. doi:10.1016/s0165-7836(99)00103-4.

61. Rideout R. Observations on mass atresia and skipped spawning in northern Atlantic cod, from Smith Sound, Newfoundland. J Fish Biol. 2000;57:1429-40. doi:10.1006/jfbi.2000.1405.

62. Rideout RM, Burton MPM. Peculiarities in ovarian structure leading to multiple-year delays in oogenesis and possible senescence in Atlantic cod, Gadus morhua L. Can J Zool. 2000;78:1840-4. doi:10.1139/z00-123.

63. Rideout RM, Morgan MJ, Lilly GR. Variation in the frequency of skipped spawning in Atlantic cod (Gadus morhua) off Newfoundland and Labrador. ICES J Mar Sci. 2006;63:1101-10. doi:10.1016/j.icesjms.2006.04.014.

64. Rideout RM, Rose GA, Burton MPM. Skipped spawning in female iteroparous fishes. Fish Fish. 2005;6:50-72. doi:10.1111/j.1467-2679.2005.00174.x.

65. Rideout RM, Tomkiewicz J. Skipped spawning in fishes: more common than you might think. Mar Coast Fish. 2011;3:176-89. doi:10.1080/194251 20.2011.556943.

66. Roff DA. Evolution of life histories: theory and analysis. New York: Chapman \& Hall; 1992.

67. Schreibman MP, Kallman KD. The genetic control of the pituitary-gonadal axis in the platyfish, Xiphophorus maculatus. J Exp Zool. 1977;200:277-93. doi:10.1002/jez.1402000209.

68. Schwindt AR, Kent ML, Ackerman LK, Simonich SLM, Landers DH, Blett T, Schreck CB. Reproductive abnormalities in trout from Western U.S. National Parks. Trans Am Fish Soc. 2009;138:522-31. doi:10.1577/ T08-006.1.

69. Silva HM. Reproduction of the forkbeard Phycis phycis (Linnaeus, 1766) in the Azorean waters. C.M. 1986/G:60. ICES Demersal Fish Committee; 1986.

70. Solemdal P. Maternal effects - a link between the past and the future. J Sea Res. 1997;37:213-27. doi:10.1016/S1385-1101(97)00029-4.

71. Stentiford GD, Feist SW. First reported cases of intersex (ovotestis) in the flatfish species dab Limanda limanda: Dogger Bank, North Sea. Mar Ecol Prog Ser. 2005;301:307-10.

72. Thorsen A, Witthames PR, Marteinsdóttir G, Nash RDM, Kjesbu OS. Fecundity and growth of Atlantic cod (Gadus morhua L.) along a latitudinal gradient. Fish Res. 2010;104:45-55. doi:10.1016/j.fishres.2010.03.020.

73. Trippel EA. Age at maturity as a stress indicator in fisheries. Bioscience. 1995:45:759-71. 
74. Trippel EA, Neil SRE. Maternal and seasonal differences in egg sizes and spawning activity of northwest Atlantic haddock (Melanogrammus aeglefinus) in relation to body size and condition. Can J Fish Aquat Sci. 2004:61:2097-110. doi:10.1139/f04-125.

75. Vieira AR, Neves A, Sequeira V, Paiva RB, Gordo LS. Age and growth of forkbeard, Phycis phycis, in Portuguese continental waters. J Mar Biol Assoc UK. 2014:94:623-30. doi:10.1017/s0025315413001549.

76. Wallace RA, Selman K. Cellular and dynamic aspects of oocyte growth in teleosts. Am Zool. 1981;21:325-43. doi:10.1093/icb/21.2.325.

77. Wild V, Simianer H, Gjoen H, Gjerde B. Genetic-parameters and genotype $x$ environment interaction for early sexual maturity in Atlantic salmon (Salmo salar). Aquaculture. 1994;128:51-65.

78. Witthames PR, et al. Advances in methods for determining fecundity: application of the new methods to some marine fishes. Fish Bull. 2009;107:148-64.
79. Witthames PR, Greer Walker M. Determinacy of fecundity and oocyte atresia in sole (Solea solea) from the Channel, the North Sea and the Irish Sea. Aquat Living Resour. 1995;8:91-109. doi:10.1051/alr:1995007.

80. Witthames PR, Thorsen A, Kjesbu OS. The fate of vitellogenic follicles in experimentally monitored Atlantic cod Gadus morhua (L.): application to stock assessment. Fish Res. 2010;104:27-37. doi:10.1016/j. fishres.2009.11.008.

81. Zanuy S, Carrillo M, Mateos J, Trudeau V, Kah O. Effects of sustained administration of testosterone in pre-pubertal sea bass (Dicentrarchus labrax L.). Aquaculture. 1999;177:21-35. doi:10.1016/S0044-8486(99)00066-6.

\section{Submit your next manuscript to BioMed Central and we will help you at every step:}

- We accept pre-submission inquiries

- Our selector tool helps you to find the most relevant journal

- We provide round the clock customer support

- Convenient online submission

- Thorough peer review

- Inclusion in PubMed and all major indexing services

- Maximum visibility for your research

Submit your manuscript at www.biomedcentral.com/submit
(O) BioMed Central 